\title{
The Current Status and Future of Central Asia's Fish and Fisheries: Confronting a Wicked Problem
}

\author{
Norman A. Graham ${ }^{1,2, *}$, Steven G. Pueppke ${ }^{2,3}$ and Talgat Uderbayev ${ }^{4}$ \\ 1 James Madison College, Michigan State University, 842 Chestnut Road, East Lansing, MI 48824, USA \\ 2 Center for European, Russian, and Eurasian Studies, Michigan State University, 427 North Shaw Lane, \\ East Lansing, MI 48824, USA; pueppke@msu.edu \\ 3 Department of Plant, Soil, and Microbial Sciences, Michigan State University, 1066 Bogue Street, \\ East Lansing, MI 48824, USA \\ 4 Department of Biodiversity and Bioresources, Al-Farabi Kazakh National University, 71 Al-Farabi Avenue, \\ Almaty 050040, Kazakhstan; talga_93@mail.ru \\ * Correspondence: ngraham@msu.edu; Tel.: +1-517-353-3372
}

Received: 16 August 2017; Accepted: 11 September 2017; Published: 14 September 2017

\begin{abstract}
Central Asia's arid lowland ecosystems are dependent on water that originates in nearby mountains and is carried by rivers to terminal lakes and freshwater seas with no outlets to the ocean. Fish traditionally thrived in these waterways, but they have become increasingly jeopardized by water impoundment and diversion for energy and crop production. Fish capture in the five new Central Asian republics consequently entered a period of long decline, a trend that was accelerated by removal of the centralized controls imposed by the former Soviet Union. Production levels have recovered during the past decade, but only in some countries. A similar trend is evident with aquaculture, which reached its lowest production levels in 2003-2008 but now is partially recovering. In both cases, progress is most evident in water-deficient Uzbekistan. Fish capture in Kazakhstan's Ili River ecosystem, including Kapchagay Reservoir and Lake Balkhash, is now dropping precipitously. Effects on the lake's fisheries have been magnified by the disproportionate rates of disappearance of valuable carp and pike-perch. The interrelationships between water, energy, and food underlie these threats to Central Asia's fish and define a classic "wicked problem" that must be addressed regionally with explicit attention given to fish as important components of the ecosystem. Recent developments, although not all positive, give reason for cautious optimism that the region's fisheries and aquaculture industries can be stabilized.
\end{abstract}

Keywords: Central Asia; Lake Balkhash; Ili River; inland fisheries; water-energy-food nexus; sustainable fisheries; aquaculture

\section{Introduction}

A landlocked region of dramatic landscape diversity, Central Asia is distant from the world's oceans. Encompassing about 4 million $\mathrm{km}^{2}$ and home to more than 60 million people, it is bracketed by the Caspian Sea, desert, and treeless steppe on the west and north and the Hindukush, Pamir, and Tian Shan mountain ranges, which form an imposing arc-shaped barrier on the south and east. Elevation falls off rapidly from the external slopes of these mountains, giving rise to the vast expanses of semi-arid plains that grade into the deserts that define most of the region. The climate is sharply continental, with large annual temperature fluctuations that lead to hot summers and cold winters. Precipitation in Central Asia generally averages between $250 \mathrm{~mm}$ and $300 \mathrm{~mm}$ per year but is highly seasonal and varies significantly with location [1]. It is greater as elevation increases, ranging from as little as $12 \mathrm{~mm}$ annually in the southwestern Karakum desert to more than $2400 \mathrm{~mm}$ in a few of the higher zones of the Pamir mountains. Exacerbated by the region's complex topography and the 
uneven distribution of moisture across space and time, water scarcity has long been a hallmark of the region [2-5].

Fish are key components of aquatic ecosystems and among the most important of Central Asia's water-dependent resources from the twin perspectives of the environment and society. Whether captured or produced via aquaculture, fish provide income and local employment, often in rural areas, and they can be a significant source of high-quality protein in human diets [6]. These benefits notwithstanding, fish have been disadvantaged by the cumulative effects of overfishing and water-management decisions that have been made over many decades [6-9]. Here, we examine this situation from a regional and systems perspective, placing emphasis on the factors most likely to govern the future viability of these important aquatic organisms. But first it is necessary to consider briefly the unusual geographical and geopolitical dynamics of the region's water resources.

\section{Water Dynamics in Central Asia}

There are two defining characteristics of water-and thus of the habitat of fish-in Central Asia (Figure 1). One is the endorheic nature of the region and surrounding areas, which means that the hydrological system is essentially closed, such that water is never released to the ocean. Instead, Central Asia's rivers either flow into terminal lakes and inland seas such as the Caspian and Aral Seas or Lake Balkhash, which lack outlets, or they simply cascade down from the mountains, dry up, and disappear before reaching any sort of larger water body. In either case, evaporation assumes an exaggerated role and, indeed, the rate of evaporation in the arid plains exceeds that with which water can be replenished there by precipitation [10].

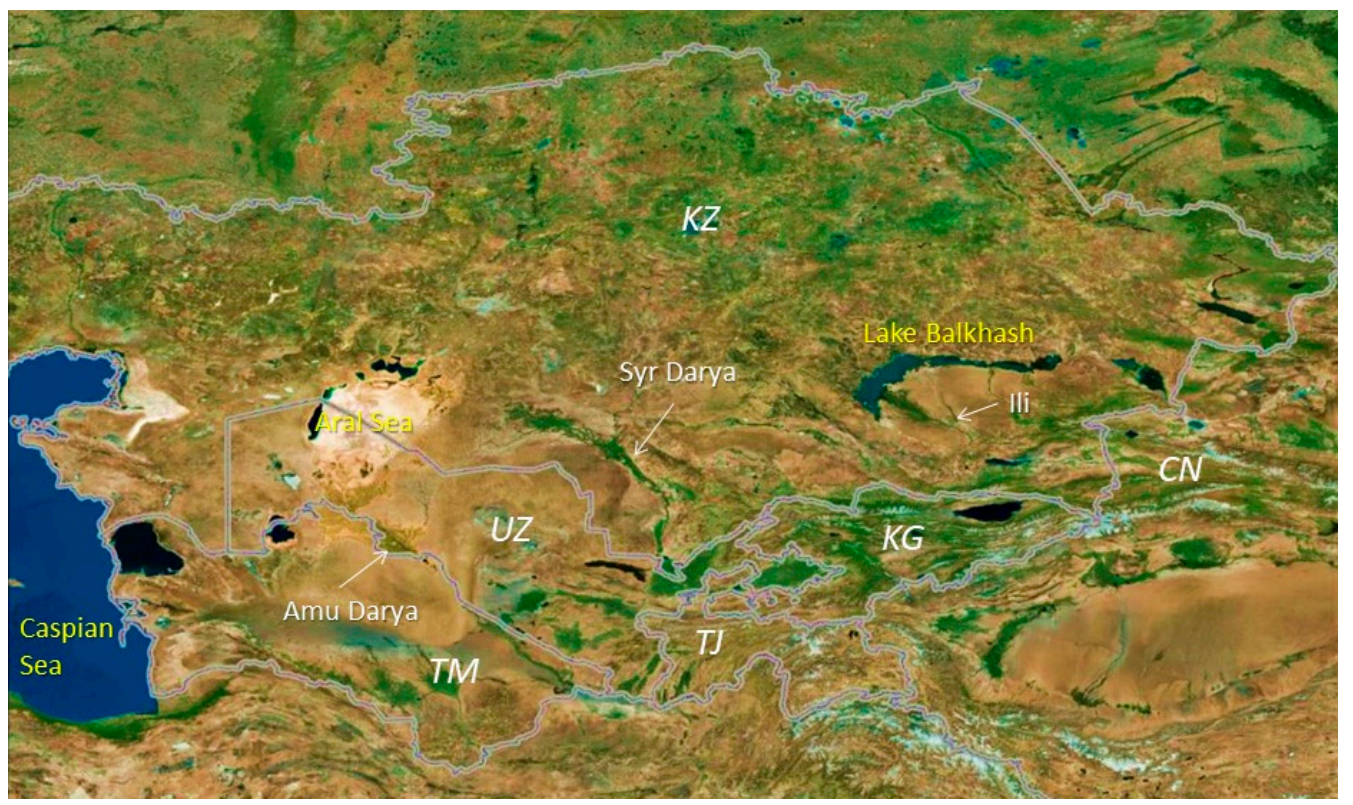

Figure 1. Satellite image of Central Asia identifying the Caspian Sea, remnant Aral Sea, and Lake Balkhash, as well as the Amu Darya, Syr Darya, and Ili rivers. Country abbreviations: CN, China; KG, Kyrgyzstan; KZ, Kazakhstan; TJ, Tajikistan; TM, Turkmenistan; UZ, Uzbekistan.

This leads to the second defining characteristic: the unusual degree to which the entire region is dependent on precipitation that falls on relatively small areas at high elevation, principally in Kyrgyzstan, Tajikistan, and parts of western China. Some of this water is retained in glaciers and high mountain lakes, but much of it is redistributed to the lower elevations of Kazakhstan, Turkmenistan, and Uzbekistan by rivers that act as water arteries. Perturbation of the water flowing into and through any of these arteries risks potential havoc with the downstream hydrological regime and the fish that inhabit it. 
Central Asia's two great rivers, whose basins adjoin one another and account for nearly one-third of the region's total land mass, illustrate these relationships. The Amu Darya arises in the Hindukush and Pamir mountains and delivers almost three times the flow of its sister, the Syr Darya, which has its origins in the Tian Shan range. Much has been written about these two waterways, which descend from higher elevations and approach the Aral Sea like pincers, the Amu Darya curving toward the southern extreme of the sea and the Syr Darya flowing northwards and gradually turning west toward the lake's northeastern shore $[5,11,12]$. Both rivers are subject to characteristic annual cycles of flow and periodic flood surges that determine when and where water is discharged.

The cumulative effects of human intervention have now overwhelmed these natural river dynamics, as water is increasingly impounded and redistributed. The Amu Darya was diverted as early as the mid-tenth century, when the great Gurganj Dam was erected to block the flow of the river's then existent channel to the Caspian Sea and redirect it to the Aral Sea [13]. Immense scale engineering of both rivers first began in the mid-twentieth century, with irrigation and hydroelectricity as dual intended benefits. Today, both rivers are interrupted by large and smaller upstream reservoirs and have been extensively engineered to supply water to networks of downstream irrigation canals and other newly created water bodies. The chronology and largely negative consequences of such imposed management on the natural state of the rivers and its underlying hydrology are well documented, especially as they relate to the desiccation of the Aral Sea [14,15].

The effects of climate change are predicted to raise average temperatures and reduce precipitation in Central Asia, further stressing the water resources of the region. Expected consequences over the coming decades include additional loss of glacier volume, alterations in the ratio of snowfall to rainfall, enhanced evaporation, and diminished total water-storage capacity within the region $[1,16,17]$. These factors will likely reduce flows of the already stressed Amu Darya and Syr Darya by one-quarter within the next 50-80 years [18], further threatening fish and complicating management of the rivers.

Although Central Asia's other major river and lake ecosystems have been investigated in lesser detail, the situation is generally similar with respect to the natural forces in operation, the extent of anthropogenic perturbations to secure irrigation water and electricity, and the looming threat posed by climate change. In each case, seemingly irreconcilable and competing demands are focusing attention, not just on water, but on its complex interlinkages with energy and food [19-22]. Fish have been heavily impacted by these competing demands, and although they are important components of Central Asia's ecosystems, they have not received the attention they deserve.

\section{Capture Fisheries and Aquaculture in Central Asia}

Figure 2 illustrates the general dimensions of the inland fisheries crisis in Central Asia. At the time of the dissolution of the Soviet Union in 1991, regional fish production was more than 110,000 metric tons. By the end of the last century, reported capture (which may under-represent total capture [7]) had dropped by roughly three-quarters before progressively recovering to about $50 \%$ of its earlier level. Substantial country-by-country differences are, nonetheless, evident. Kazakhstan and Turkmenistan accounted for $61 \%$ and 36\%, respectively, of Central Asia's 1991 fish capture, with most of the residual production in Uzbekistan. Although Tajikistan's fish capture has increased in recent years, its production and that in Kyrgyzstan, the other mountainous, water-rich country, was and remains negligible. Mirroring the region as a whole, Kazakhstan has since 2000 managed to stabilize and then slowly increase fisheries production to about half of its pre-independence level. Turkmenistan was not so fortunate; its capture fisheries industry has stabilized at a level well below $40 \%$ of the pre-independence level and shows no signs of further recovery. Never a major fisheries player, Uzbekistan is the only Central Asian state where current fisheries capture exceeds that prior to independence; progress in recent years has been rapid and sustained. 

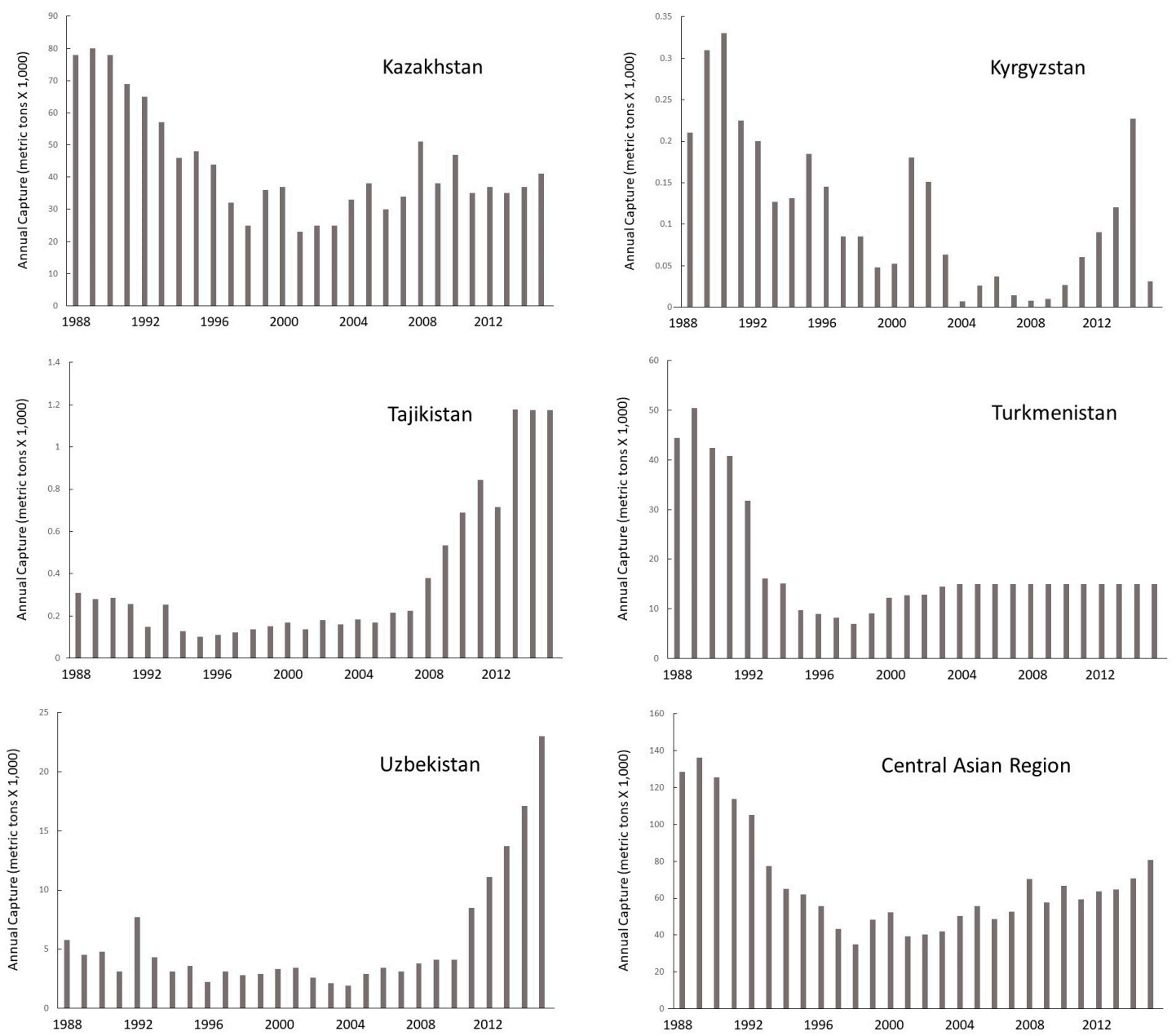

Figure 2. Estimated annual fish capture (in metric tons) in the five individual countries of Central Asia and the region as a whole between 1988 and 2015 (Sources: www.fao.org and www.worldbank.org/ indicator/ER.FSH.PROD.MT).

Aquaculture in Central Asia enjoyed a long history of development and sustained support during Soviet times. With government encouragement, the output of fish farms reached almost 260,000 metric tons by 1990 before plummeting following the demise of the Soviet Union [23]. The fate of aquaculture in Central Asia followed a similar trajectory (Table 1), as most farms were unable to operate profitably without state support. Production in all five newly independent states reached a low point between 2003 and 2008, at which time yields in Kyrgyzstan, Tajikistan, and Turkmenistan were virtually nil. By 2015, production in each of these countries had recovered somewhat, but none is a major player today.

The aquaculture sectors of Kazakhstan and Uzbekistan diverged sharply between 1991 and 2015 (Table 1). Although aquaculture production in the former remains at less than $5 \%$ of its previous level, Uzbekistan has managed to boost its production to a level exceeding that achieved under the Soviets by more than $50 \%$. This likely reflects both Uzbek priorities and the attention paid to large-scale aquaculture infrastructure that was created by the Soviets to offset the decline in capture fisheries accompanying destruction of the Aral Sea [7,24]. 
Table 1. Fish production in aquaculture from the collapse of the Soviet Union in 1991 to 2015 (Source: World Bank (www.worldbank.org).

\begin{tabular}{cccccc}
\hline \multirow{2}{*}{ Country } & \multicolumn{2}{c}{ Aquaculture Fish Production } & \multicolumn{2}{c}{ Lowest Production } \\
\cline { 2 - 6 } & $\mathbf{1 9 9 1}$ (Tons) & $\mathbf{2 0 1 5}$ (Tons) & Change (\%) & Year & Tons \\
\hline Kazakhstan & 13,382 & 730 & -95 & 2005 & 123 \\
Kyrgyzstan & 974 & 1068 & +10 & 2003 & 12 \\
Tajikistan & 3689 & 450 & -88 & $2004-2008$ & 26 \\
Turkmenistan & 2248 & 30 & -99 & 2004 & 16 \\
Uzbekistan & 24,316 & 36,898 & +52 & 2004 & 3093 \\
\hline
\end{tabular}

As Table 1 indicates, Kazakhstan achieved only moderate success in utilizing old Soviet aquaculture infrastructure. As of 1994, there were only 18 such facilities in operation (Table 2), distributed among 12 of the country's 14 districts [25]. Many functioned as hatcheries or nurseries for carp and related herbivorous species, but several near Almaty (including the only two in private hands) were engaged in commercial production. Lack of access to water and fish food, as well as free-market pressures, stand out as operating challenges $[7,26]$.

Table 2. Location and specialization of Kazakhstan's aquaculture facilities as of 1994. The information is based on data available in [25].

\begin{tabular}{lcl}
\hline \multicolumn{1}{c}{ District } & Number of Facilities & \multicolumn{1}{c}{ Major Cultured Species } \\
\hline Akmola & 2 & Carp, cisco, whitefish \\
Aktobe & 1 & Carp, sturgeon, herbivorous species \\
Almaty & 6 & Carp, spadefish, herbivorous species \\
East Kazakhstan & 1 & Carp \\
Karagandy & 1 & Carp \\
Kostanay & 1 & Carp \\
Kyzylorda & 1 & Carp and herbivorous species \\
North Kazakhstan & 1 & Carp and cisco \\
Pavlodar & 1 & Carp \\
South Kazakhstan & 1 & Carp and herbivorous species \\
West Kazakhstan & 1 & Carp, sturgeon, and herbivorous species \\
Zhambyl & 1 & Carp and herbivorous species \\
\hline
\end{tabular}

A March 2016 visit by the first and second authors to the Chilik Pond Farm near the Kapchagay Reservoir in southeastern Kazakhstan revealed serious efforts to modernize old Soviet era infrastructure for aquaculture (Figure 3). The farm had been privatized with investment from Astana Capital Invest and had achieved considerable success in the introduction of new technology, production, and marketing systems. The farm produces fish for local markets, for the Kazakh government's restocking program, and supplies fingerlings to local fishers, who are obligated to help ease the overfishing problem in the Kapchagay Reservoir by restocking to offset their own catches. The long-term goal is to expand dramatically the export of pike-perch fillets to the European Union, especially Poland. Delivery is via long-haul, refrigerated trucks that must travel nearly two weeks to reach their destination in Europe [26]. There is potential to increase exports of pike-perch, trout, and sturgeon to China, as well as new opportunities with the Russian Federation, given President Putin's decision to ban food imports from Europe. 

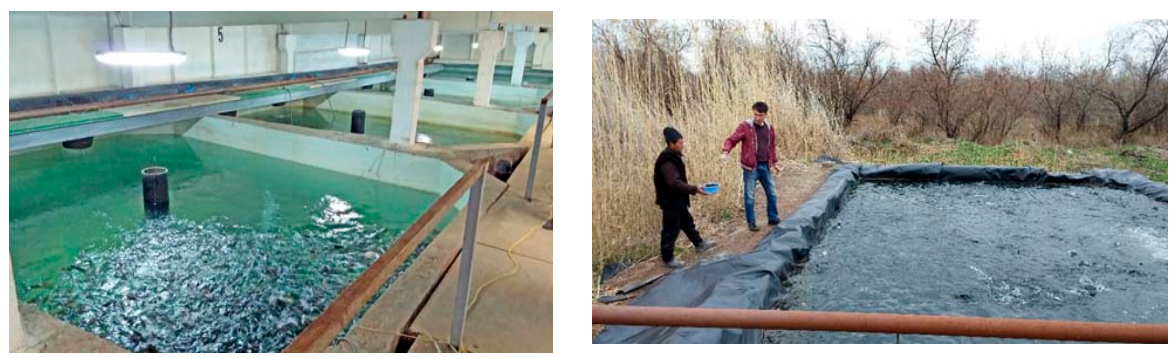

Figure 3. (Left) Interior fish tanks and (Right) outside ponds at the Chilik Pond Farm in 2016.

\section{Water-Energy-Food Impacts on Fisheries and Aquaculture in Central Asia}

The collapse of inland fisheries in Central Asia derives in large part from the intricate water-energy-food nexus in the region. More than $90 \%$ of this arid region's water is withdrawn for irrigation [19], a figure significantly higher than the global average [27]. All of the region's major rivers are interrupted by reservoirs, many of which generate hydroelectric power and all of which disrupt the hydrological cycle [28-30]. Upstream countries with abundant water resources are deficient in fossil fuel resources and, vice versa, downstream countries have fossil fuels but are water-deficient. Consequently, there is pressure on water-rich countries such as Kyrgyzstan and Tajikistan to increase hydroelectric generation capacity-moves opposed by the other downstream oiland gas-rich countries, which claim substantial water flows for elaborate irrigation efforts. Added to this imbalance is the legacy of misguided Soviet agricultural and environmental policies that diverted water resources for unsustainable agricultural production goals on the one hand and permitted the unfettered industrial pollution of rivers, lakes, and seas on the other [31-34].

The Soviet water and energy transmission network may have made some sense in Moscow for the goals of economic self-sufficiency and heavy industrialization under Stalin and his immediate successors, but the damage done to the natural environment and to the prospects for prosperity in the successor Central Asian republics is appalling. The network of water and energy transmission managed centrally from Moscow in Soviet times has disintegrated into decaying infrastructures managed by national authorities beset with conflicting domestic imperatives and seemingly myopic policy priorities that are complicated in most cases by limited economic resources [34-38]. It is against this backdrop that fish production in the Soviet Union and its successor republics in Central Asia dropped sharply and then recovered modestly. Although the reasons are complex and vary from republic to republic [7], three major factors emerge.

First, the collapse of the Soviet economy was dramatic and far-reaching. With the subsequent collapse of the Soviet Union as a political entity, the tasks for each successor state in the dual challenges of building both new political institutions and a productive economic system were immense. The common, one-size-fits-all Western advice of democratization and economic liberalization was not adopted to a significant degree in this region, and when some elements of the suggested reforms were adopted, they were only modestly effective [25,32,34-38]. One can argue that the political leadership in each country was distracted by more pressing governance and economic development challenges in the early years of independence-indeed civil war raged on in Tajikistan during the early years. More pedestrian, but nonetheless evident, was the fact that most of the regimes were more focused on other elements of economic and development policies. Fishery policy was well down the list of reform priorities, as indeed were agricultural reform and rural development more generally $[7,10,39,40]$.

Second, the long-term negative environmental impacts of policies begun under the Soviet regime affected all five countries to some extent, destroying habitat and reducing and even eliminating formerly productive fisheries. These actions were long in the making and their legacy not easily remediated. The most striking fact is that until recently, and then only partially, none of the successor regimes sought to address the most important root issues such as the harmful pursuit of expansive hydroelectric generation strategies that dramatically disrupt fish habitat. The cultivation 
of inappropriate crops like cotton and rice in arid regions also inflicts damage via excessive evaporation, waterlogging and salinization of the soil, erosion, and accumulation of pesticides [41,42].

As described above, the desertification of the Aral Sea in Kazakhstan and Uzbekistan is the most striking, but not the only [41,43], example of the convergence of this tragic set of policies. The elimination of this formerly productive fishery had obvious direct impacts on the livelihoods of the fishers. Destruction of the sub-region and its broader population through the secondary impact of soil encrusted with salt and poisoned by pesticide runoff, and then spread through the air by dust storms, was nothing short of devastating [14,44,45]. There is some hope for the recent efforts at rehabilitation, at least on the Kazakh side of the lake [15,42], but the newly independent governments still mostly choose not to turn their backs on the Soviet policies and system that had wreaked havoc on fish habitat and the larger environment $[44,46]$. This is occurring even though Soviet imperial policies of self-sufficiency are no longer in play as a political justification for bad economics and agriculture, especially in the increasingly globalized economy of the post-Cold War world.

The third set of factors that explain the collapse of inland fisheries relates to the crucial energy-water nexus operative in much of the region. Countries with abundant water resources (Kyrgyzstan and Tajikistan) are deficient in fossil fuel resources, while oil- and gas-rich countries (Kazakhstan, Turkmenistan, and Uzbekistan) are downstream from and dependent on their neighbors for the liquid that creates fish habitat and enables irrigated agriculture [2,8]. The pressure on water-rich countries to increase hydroelectric generation capacity is clear, but such action is usually opposed by downstream oil- and gas-rich countries, which claim a right to substantial water flows for elaborate irrigation efforts in support of the cotton monoculture, but secondarily for fishery rehabilitation [46].

Countries with abundant water resources have not generally been able to monetize this resource, at least not to the extent that the fossil fuel-rich countries have been able to do so. Schemes to compensate water drawdown with energy resource transfers, while the subject of serious negotiation and some agreements, most notably between Uzbekistan and Tajikistan, have not worked well [47,48]. Indeed, the Uzbeks in the past have threatened recourse to military action in response to potential cuts in water flows [49]. Irrigation needs are problematic due to aging and poorly maintained infrastructure, harsh climate, and soil-quality deficiencies, but they are also driven by the surprising survivability of the legacy of Soviet cotton monoculture in the region. A Russian or Chinese role in helping to reduce tension and mediate the conflicts of interest, which the Soviets helped to create, would be a valuable contribution to the region, whether it comes bilaterally or as part of a larger multilateral effort. To date, this has not occurred, in part because these two major powers have water and energy needs of their own that must be met $[8,50]$.

Tajikistan offers the clearest example of a predominant focus on hydroelectric generation capacity development without due consideration for regional impacts on water and food, including fish. Trailing only Russia, it has the second highest hydroelectric power generation capacity of the Commonwealth of Independent States [8]. The Rogun Dam has been especially controversial [51]. Intended to solve Tajikistan's annual winter energy crisis with an expected installed capacity of 3600 megawatts, it may also displace 42,000 people from surrounding mountain villages. The World Bank has been reluctant to commit financing to the project, but the Tajik government in a 2015 ceremony announced its intention to complete the dam, and construction commenced in November 2016 [52].

Uzbekistan protested plans to construct the dam by withdrawing in 2009 from Central Asia's electricity generation network $[8,48]$. The death of the long-time Uzbek president Islam Karimov in September 2016 has raised the prospect of new, more sustainable policies on water use and agricultural development, and of potential cooperation with Tajikistan. Karimov's successor, the former prime minister Shavkat Mirziyoyev, has signaled his interest in reducing the production of water-intensive crops like cotton and rice as part of a large-scale program of economic and agricultural reform. While the Aral Sea fisheries may be beyond the reach of even the most aggressive plan for reclamation, recent growth in fish capture and aquaculture production in Uzbekistan (Table 1, Figure 2) bodes well for the future. 


\section{Observations from the Ili River and Lake Balkhash}

Although the renewable freshwater resources of Kazakhstan exceed those of Japan on a per capita basis [53], water is unevenly distributed over an immense area of low population, and thus often scarce. The internal rivers are small with limited flow and, as discussed above, the larger ones are mostly transborder in nature, originating in mountainous regions of nearby countries. Among these rivers is the Ili, which rises in Xinjiang Province of western China and flows in a westerly direction toward Lake Balkhash (Figure 4). The river enters the lake through a biodiverse and economically important delta and then terminates. Lake Balkhash lies in a particularly arid region that receives only about $130 \mathrm{~mm}$ of precipitation per year in comparison to more than 400 and $600 \mathrm{~mm}$, respectively, in northern Kazakhstan and the Almaty region [1].

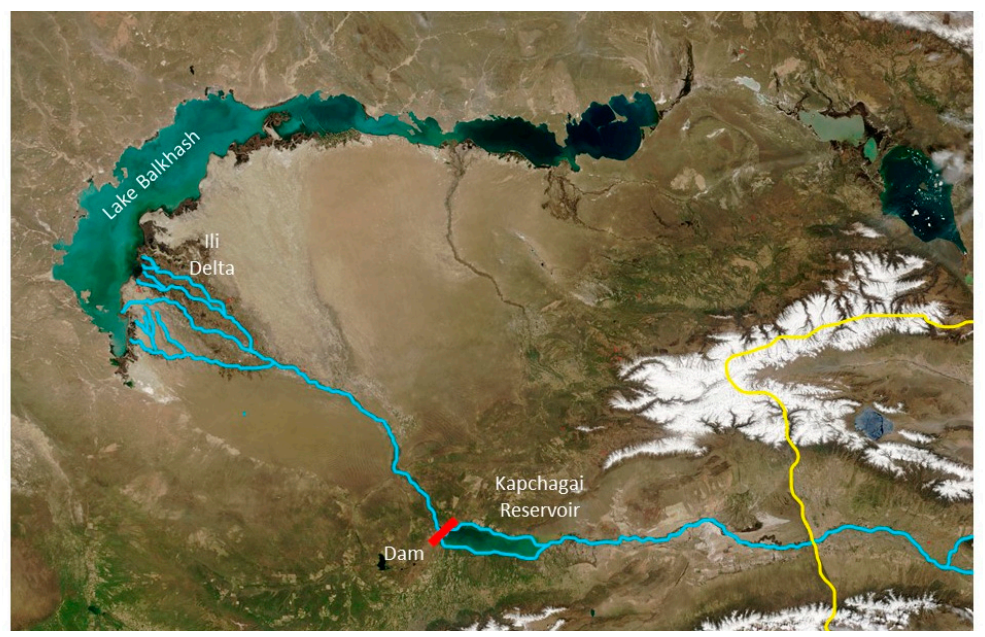

Figure 4. The Ili River ecosystem, including Kapchagay Reservoir, the delta, and Lake Balkhash. The yellow line marks the Kazakhstan-China border.

The Ili River ecosystem has been examined from a variety of perspectives, both because of its uniqueness and its fragility [43,54-57]. The river is interrupted by one major dam at Kapchagay in eastern Kazakhstan and by several smaller dams along its headwaters in China. Kapchagay dam and reservoir, which were installed by the Soviets in the late 1960s, were designed to generate about 300 megawatts of power and simultaneously enable irrigation of arid lands downstream and near the reservoir, primarily for rice [58]. The extent of irrigation from Kapchagay never reached expectations and, following a familiar pattern, declined substantially after the disappearance of the Soviet Union. In contrast, China's newer, more modest-sized upstream dams continue to perform dual functions in irrigation and power generation [59].

Capture fisheries along the Ili and its feeder streams in China are insignificant compared to those in Kazakhstan, which began on Lake Balkhash and have extended more recently to Kapchagay reservoir. Officially, commercial fishing began in Lake Balkhash in 1929. Capture was initially under 100 tons per year, but yields gradually rose until 1941, when they exceeded 18,000 tons and then declined by two-thirds in just four years [39,43]. During the 1960s, just prior to the closing of the Kapchagay dam, capture often exceeded the peak achieved more than 20 years earlier, and Lake Balkhash fisheries were economically healthy as assessed by employment, efficiency, and equipment (Table 3).

The completion of Kapchagay dam in the fall of 1969 had profound negative impacts on the downstream river, delta, and lake. The altered hydrological cycle and increased pesticide load and salinity-both conditioned in large part by irrigated agriculture-reduced the fisheries' potential in the lake to the extent that by the 1990s, at a time when capture was about 11,000 tons per year and experiencing a long period of decline [60], sustainable annual yields of only 7000 tons were 
predicted [39,61]. Newly available data for the years 2010, 2011, and 2016 confirm that although this level was exceeded well into the 21st century, capture is now falling and approaching the 7000 tons per year estimate (Table 4). The makeup of the catch also seems to be changing, as yields of valuable carp and pike-perch have fallen disproportionately over the past few years in comparison with those of less-valuable species such as asp and roach.

Table 3. Commercial catches and fishing operations on Balkhash Lake (1960-1966) (Source: Kazakh Research Institute of Fishery).

\begin{tabular}{cccccc}
\hline Year & Fishers & Total Catch (Tons) & Average Catch Per Fisher (Tons) & Seines in Use & Fishnets in Use \\
\hline 1960 & 664 & 8870 & 13.4 & 66 & 23,000 \\
1961 & 574 & 8850 & 15.4 & 55 & 28,000 \\
1962 & 641 & 11,810 & 18.4 & 65 & 27,900 \\
1963 & 724 & 13,450 & 18.6 & 72 & 30,100 \\
1964 & 781 & 15,040 & 19.3 & 77 & 24,600 \\
1965 & 787 & 16,170 & 20.6 & 88 & 31,500 \\
1966 & 775 & 16,500 & 21.3 & 32,000 \\
\hline
\end{tabular}

Table 4. Commercial fish capture from Lake Balkhash during the second decade of the 21st century. * data are estimates for the year. (Sources: Data are from the Kazakh Research Institute of Fishery; for fish names, see: FishBase.org).

\begin{tabular}{ccccc}
\hline \multirow{2}{*}{ Species } & \multicolumn{4}{c}{ Commercial Catch (Tons) } \\
\cline { 2 - 5 } & $\mathbf{2 0 1 0}$ & $\mathbf{2 0 1 1}$ & $\mathbf{2 0 1 6}$ & $\mathbf{2 0 1 7}$ \\
\hline Asp (Aspius aspius) & 290 & 320 & 296 & 324 \\
Common carp (Cyprinus carpio) & 910 & 1060 & 483 & 482 \\
Freshwater bream (Abramis brama) & 5040 & 5047 & 4801 & 4604 \\
Goldfish (Carassius auratus) & 230 & 236 & 79 & 145 \\
Pike-perch (Sander luciopera) & 1210 & 1324 & 697 & 554 \\
Roach (Rutilus rutilus) & 300 & 315 & 303 & 312 \\
Snakehead (Channa argus) & No data & No data & 50 & 50 \\
Volga pike-perch (Sander volgensis) & 200 & 209 & 142 & 102 \\
Wels catfish (Silurus glanis) & 890 & 938 & 701 & 735 \\
TOTAL CATCH & 9070 & 9449 & 7552 & 7308 \\
\hline
\end{tabular}

Table 5 provides data on the number of fishers and the size of the fleet on Lake Balkhash for the time interval corresponding to the capture data shown in Table 4. Employment of fishers on the lake, as well as the number of boats and the number of seines and nets in use, are declining even more rapidly than the reductions in capture, but in rough proportion to the disappearance of the more valuable fish species from the total capture. This implies that fishers are responding to decreased stocks of desirable species by reducing their activity on the lake.

Table 5. Fishing employment and fleet on Lake Balkhash 2010-2015. * data based on 8 months of observation. (Source: Kazakh Research Institute of Fishery).

\begin{tabular}{cccccc}
\hline Year & Fishing Firms & Fishers & Self-Propelled Boats & Seines in Use & Fishnets in Use \\
\hline 2010 & 39 & 1090 & 433 & 89 & 12,275 \\
2011 & 33 & 1122 & 192 & 68 & 11,795 \\
2012 & 24 & 506 & 208 & 75 & 5500 \\
2013 & 28 & 459 & 191 & 53 & 5180 \\
2014 & 28 & 618 & 154 & 41 & 7350 \\
$2015^{*}$ & 26 & 447 & 242 & 58 & 5849 \\
\hline
\end{tabular}

Although the lake is the predominant source of fish in the Ili River ecosystem, fish are also caught in the river and its delta, as well as Kapchagay reservoir. The yield from the river and delta corresponds to less than 3\% of that from the lake, and plummeted between 2011 and 2016 (Table 6). All species experienced declines, some by more than $80 \%$ in just five years. Commercial fishing on the reservoir 
began shortly after its inception, with capture varying from 660 to 1250 tons annually between 1975 and 1984. Twenty-four species, some native and some introduced, were present at the beginning of this period, but the number declined to 19 by 1980, even as the relative proportions of species fluctuated substantially [39]. This was conditioned in part by changes in water flow characteristics and food availability as the impoundment filled, but other long-term factors were also at play. These include fishing pressure upstream [39], diversion of ever more upstream water for hydroelectric and irrigation projects in China [58,59], as well as climate change [17,62]. The latter driver is of particular importance. Warming of temperatures in Kazakhstan and the neighboring mountains is much higher than the global average of $2{ }^{\circ} \mathrm{C}$. The glacier melt is predicted to increase flow into the Ili and other rivers temporarily, but then lead to sustained decreases as the glaciers disappear [17].

Table 6. Commercial fish capture in the Kazakhstan portion of the Ili River and the Ili River delta during the second decade of the 21st century. * data are estimates for the year. (Sources: Data are from the Kazakh Research Institute of Fishery; for fish names, see FishBase.org).

\begin{tabular}{ccccccccc}
\hline & \multicolumn{7}{c}{ Commercial Catch (Tons) } \\
\cline { 2 - 9 } Species & \multicolumn{5}{c}{ Ili River } & \multicolumn{4}{c}{ Ili River Delta } \\
\cline { 2 - 9 } & $\mathbf{2 0 1 0}$ & $\mathbf{2 0 1 1}$ & $\mathbf{2 0 1 6}$ & $\mathbf{2 0 1 7}$ & $\mathbf{2 0 1 0}$ & $\mathbf{2 0 1 1}$ & $\mathbf{2 0 1 6}$ & $\mathbf{2 0 1 7}$ \\
\hline Asp (Aspius aspius) & 31.8 & 32.1 & 7.3 & 7.3 & 52.5 & 54 & 22.8 & 22.6 \\
Common carp (Cyprinus carpio) & 88.5 & 80.0 & 15.2 & 15.2 & 120 & 119 & 15.1 & 15.1 \\
Freshwater bream (Abramis brama) & 23.8 & 22.9 & 2.9 & 4.8 & 34 & 32 & 5.3 & 5.3 \\
Goldfish (Carassius auratus) & 19.1 & 19.8 & 6.0 & 6.0 & 25 & 25 & 5.8 & 5.8 \\
Grass carp (Ctenopharyngodon idella) & 14.9 & 12.2 & 0.6 & 0.7 & 9.2 & 8 & 2.6 & 3.3 \\
Pike-perch (Sander luciopera) & 40.0 & 34.9 & 4.2 & 4.2 & 68.3 & 76 & 16.1 & 16.1 \\
Roach (Rutilus rutilus) & 24.2 & 22.8 & 6.0 & 6.0 & 25 & 27 & 18.8 & 18.7 \\
Snakehead (Channa argus) & $\mathrm{ND}$ & $\mathrm{ND}$ & 1.3 & 1.3 & ND & ND & 8.7 & 8.7 \\
Volga pike-perch (Sander volgensis) & 7.2 & 7.7 & 1.5 & 1.5 & 17 & 16 & 4.6 & 4.6 \\
Wels catfish (Silurus glanis) & 70.5 & 74.8 & 29.3 & 29.3 & 207 & 225 & 43.2 & 42.8 \\
T0TAL CATCH & 320.0 & 307.0 & 74.3 & 76.3 & 558 & 582 & 143 & 143 \\
\hline
\end{tabular}

Traveling from the Kapchagay dam along the Ili River to Lake Balkhash in May, one is struck by the vastness and aridity of the region. Remnants of the old Soviet irrigation network, long inoperable and with little prospect for renewed agricultural development, are visible near Bakbakty. The slow-moving river is dotted with islands and sandbars near the bridge crossing at Akzhar, where exposed banks are evidence that the river's flow has been altered (Figure 5). Little of the delta is visible as one nears the village of Kuygan, which is adjacent to the lake and home to the Ribprom fishing enterprise, which operates approximately 12 boats.
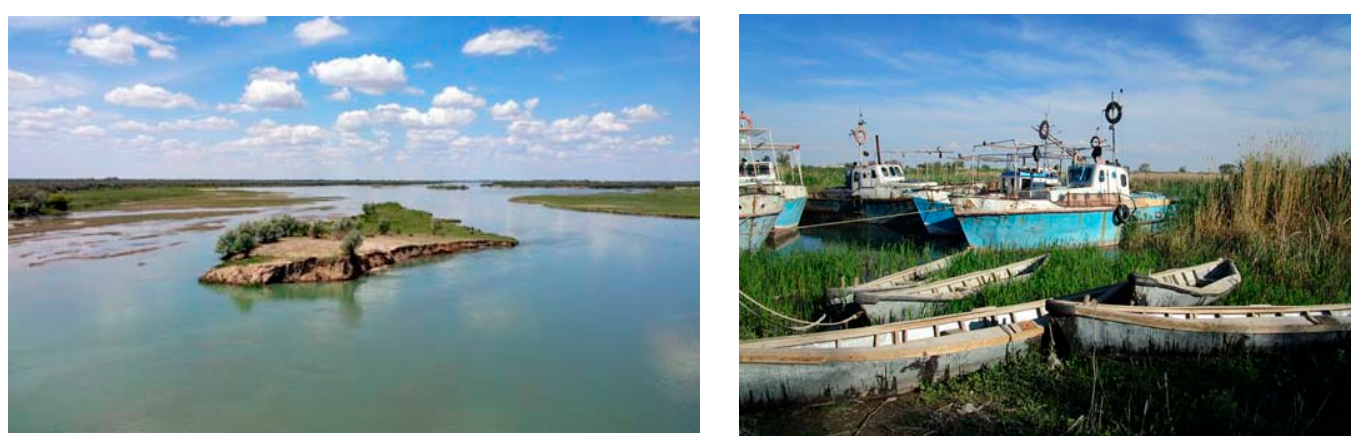

Figure 5. (Left) The Ili River near Akzhar, Kazakhstan; (Right) Fishing boats on the channel to Lake Balkhash at Kuygan, Kazakhstan.

In order to maintain adequate stocks, capture is not permitted between 15 April and 31 May. This period is thus reserved for boat and tackle repairs in anticipation of the summer fishing season, when boats are allowed to cross an 11-km channel fed by the Ili River to reach Lake Balkhash (Figure 5). June is the prime fishing month, with the goal to capture 20 tons per day (daily production usually 
drops to no more than $4-5$ tons for the remaining season). The fishers use a seine net that is $1500 \mathrm{~m}$ long and pulled by two boats, each with a four-man crew. The net size is regulated, permitting square openings no smaller than $4.5 \times 4.5 \mathrm{~cm}$. One pass requires about four hours. Commercial enterprises purchase fish from independent fishers and combine them with their own catch before shipment on ice to Almaty, a $4-5 \mathrm{~h}$ drive, for processing.

In the past, carp and pike-perch were the principal fishing targets, but as stocks of these species have declined (Table 4), the catch is mostly less marketable bream, some of which is hung to dry before sale. Fishers adhere to government fishing regulations but complain about lax enforcement and rampant poaching on the lake, practices that are known to be widespread in Kazakhstan [31]. As with enforcement of fishery regulations in many other depressed jurisdictions, the government may also be reluctant to deal too harshly with a struggling and underemployed rural population.

\section{The Path Forward}

Centralized control during Soviet times, although environmentally reckless, did assure a significant degree of systems integration $[20,63]$. The use of natural resources was balanced by Moscow, ostensibly for the "common good," and this benefitted fish production. Moscow even exerted pressure to increase fish consumption via a 1976 degree that identified Thursday as Fish Day [64]. This all changed with the breakdown of the old order and the rise of new republics that emphasized self-sufficiency and nation-building $[8,65]$. As we have seen, resources are unevenly distributed across today's political map such that some of the newly independent states are dependent on others for water, energy, and food. This set the stage for disagreements, many of which are ongoing more than 25 years after independence.

Preservation of Central Asia's ecosystems, including the fish that inhabit them, can be viewed as a so-called wicked problem [66]. These problems exhibit complex interdependencies, i.e., water-energy-food, and are characterized by evolving and contradictory information and knowledge, as well as core issues that often include a strong economic component. Wicked problems can best be addressed by posing questions that begin with "what ought to be" rather than "what if". This shifts attention from specific components of the ecosystem (What if a particular river is dammed? What if fish capture in a particular lake continues to decrease?) to real world interdependencies (What ought to be the distribution of the ecosystem's available water? What ought to be the value of biota in the ecosystem?). Identification and analysis of such interdependencies between water, energy, and food is a valuable way to highlight the importance of individual components, including fish [67-70].

Table 7. Recent policy developments that impact the future of fish and fisheries in Central Asia. Country abbreviations: CN, China; KG, Kyrgyzstan; KZ, Kazakhstan; RU, Russia; TJ, Tajikistan; TM, Turkmenistan; UZ, Uzbekistan.

\begin{tabular}{|c|c|c|}
\hline Issue & Country & Development \\
\hline \multirow{3}{*}{$\begin{array}{l}\text { Preservation of } \\
\text { natural waterways }\end{array}$} & $\mathrm{CN}$ & Continued substantial diversion of water from the upper Ili River [71] \\
\hline & $\mathrm{KZ}$ & Continued investments planned to revive the North Aral Sea [72] \\
\hline & TM & Diversion of irrigation and Amu Darya water to create Golden Era Lake in Karakum desert [73] \\
\hline \multirow{4}{*}{$\begin{array}{l}\text { Irrigation and water } \\
\text { use efficiency }\end{array}$} & $\mathrm{KZ}$ & Government announces plans to increase irrigated cropland by $45 \%$ over five years [74] \\
\hline & $\mathrm{KZ}$ & $\begin{array}{l}\text { European Bank of Reconstruction and Development and the World Bank fund projects to increase } \\
\text { irrigation efficiency }[75,76]\end{array}$ \\
\hline & TM & Government proposes to end wasteful water subsidies [77] \\
\hline & $\mathrm{UZ}$ & New president signals ending of the country's addiction to water-intensive cotton [78] \\
\hline \multirow{3}{*}{$\begin{array}{l}\text { Governance and } \\
\text { international } \\
\text { cooperation }\end{array}$} & $\mathrm{CN}$ & Water concessions anticipated as part of New Silk Road and One Belt, One Road initiatives [79] \\
\hline & KG & Government cooperating on new initiatives to mitigate the effects of climate change [80] \\
\hline & $\mathrm{UZ}$ & New president is open to regional cooperation [81] \\
\hline \multirow{3}{*}{$\begin{array}{l}\text { Fisheries and } \\
\text { aquaculture }\end{array}$} & KG & Finland funds fisheries and aquaculture research, in-country fish processing [82] \\
\hline & RU & $\begin{array}{l}\text { Significant new domestic fish-processing capacity in the Crimea to reduce imports from other } \\
\text { countries [83] }\end{array}$ \\
\hline & TJ & Program to expand fisheries and develop aquaculture extended to 2020 [84] \\
\hline
\end{tabular}


Freeing fish and fisheries from their current, disproportionately subordinate status as a food source is also important. Collection of statistics on fish populations and species diversity, catch, and the potential of aquaculture such as those given in Tables 3-6 is a useful first step. The value of such data has been heightened by complications triggered by the disintegration of the Soviet Union and the diminished importance of fish in the newly emerged Central Asian states, but documentation, while necessary, is not enough. At a time when attention is rapidly shifting away from sector-specific perspectives and toward the interdependencies between water, energy, and food, what additional information about fish is needed and how can it best be obtained?

The above issues cannot be separated from the policy path for Central Asia's fish and fisheries. Four steps are important. The first is adoption of regional accords and harmonization of national policies on catch limits and allowable fishing equipment. Such policies have proved effective across the European Union, where enforcement of rules helped to curtail overfishing, allowing stocks to recover [85]. Second, transborder water-sharing must be addressed as a mechanism to conserve and appropriately manage this limiting, shared resource. As a source of Central Asian waterways, China must be party to these negotiations. Third, research and development in support of aquaculture should be pursued as a strategy to replace collapsed fisheries that cannot be revived. And fourth, essential hydroelectric generation capacity in upstream areas without effective energy alternatives should be expanded within a framework of environmental impact assessment that mandates strategies to reduce potential fish habitat loss.

Sound policy may nevertheless be difficult to implement given today's political realities [86,87]. Indeed, the Kazakh government in 2007 extended an offer to China for reduced pricing of its exports, perhaps including future oil and gas shipments, in return for lower water consumption on the Chinese side of the border. China's reported decline of the offer is indicative of the complexity surrounding current and likely future negotiations on water, energy, and food. Regional discussion nevertheless continues, and decisions are being made (Table 7). Thus, the future of the North Aral Sea seems assured, even as draw-off of excess irrigation water to fill the Golden Era Lake further threatens the Amu Darya River, and as China persists in diverting water from the headwaters of the Ili River. Investments are making irrigation more efficient but also more extensive, even as several countries in Central Asia signal a new willingness to at least discuss contentious water issues. Investments to enhance aquaculture and fish-processing have also been announced. Few of these efforts are driven by a desire to support fish and inland fisheries, but many have the potential to do so.

Recognition of the systems interdependencies governing fish and fisheries in Central Asia is no more a panacea than acknowledgment that the underlying ecosystems should be addressed as wicked problems. The history of the region is, after all, replete with bad environmental decisions that have been made in spite of the availability of good information to the contrary. Nevertheless, the time seems appropriate for renewed emphasis on fish and fisheries as they relate to the convergence of water, energy, and food in Central Asia.

Acknowledgments: The authors acknowledge S. Nurtazin and members of his research group at Al-Farabi Kazakh National University for helpful suggestions during the preparation of the manuscript.

Author Contributions: N. Graham and S. Pueppke analyzed the data and shared writing responsibilities equally. T. Uderbayev provided data and assisted in data analysis.

Conflicts of Interest: The authors declare no conflict of interest.

\section{References}

1. Chen, F.H.; Huang, W.; Jin, L.Y.; Chen, J.H.; Wang, J.S. Spatiotemporal precipitation variations in the arid Central Asia in the context of global warming. Sci. China Earth Sci. 2010, 54, 1812-1821. [CrossRef]

2. Zhupankhan, A.; Tussupova, K.; Berndtsson, R. Could changing power relationships lead to better water sharing in Central Asia? Water 2017, 9, 139. [CrossRef]

3. Porkka, M.; Kummu, M.; Siebert, S.; Flörke, M. The role of virtual water flows in physical water scarcity: The case for Central Asia. Water Res. Dev. 2012, 28, 453-474. [CrossRef] 
4. Varis, O.; Kummu, M. The major Central Asian river basins: An assessment of vulnerability. Water Res. Dev. 2012, 28, 433-452. [CrossRef]

5. Asian Development Bank. Central Asia Atlas of Natural Resources; ADB: Manila, Philippines, 2010.

6. Thorpe, A.; Van Anrooy, R. Inland Fisheries Livelihoods in Central Asia. Policy Interventions and Opportunities; Food and Agriculture Organization of the United Nations: Rome, Italy, 2009.

7. Thorpe, A.; Van Anrooy, R. Strategies for the rehabilitation of the inland fisheries sector in Central Asia. Fish. Manag. Ecol. 2010, 17, 134-140. [CrossRef]

8. Campins Eritja, J.; Saura Estapa, J.; Pons Rafols, X. Towards improved regional co-operation over water uses in Central Asia: The case of hydroelectric energy and inland fisheries. Asian J. Int. Law 2016, 6, 119-158. [CrossRef]

9. Thorpe, A.; Van Anrooy, R.; Niyazov, B.N.; Sarieva, M.K.; Valbo-Jørgensen, J.; Millar, A.M. The collapse of the fisheries sector in Kyrgyzstan: An analysis of its roots and its prospects for survival. Communist Post Communist Stud. 2009, 42, 141-163. [CrossRef]

10. Petr, T. (Ed.) Fisheries in Irrigation Systems of Arid Asia; Food and Agricultural Organization of the United Nations: Rome, Italy, 2003.

11. Asarin, A.E.; Kravtsova, V.I.; Mikhailov, V.N. Amudarya and Syrdarya rivers and their deltas. In The Aral Sea Environment; Kostianoy, A.G., Kosarev, A.N., Eds.; Springer: Berlin, Germany, 2010.

12. Schlüter, M.; Herrfahrdt-Pähle, E. Exploring resilience and transformability of a river basin in the face of socioeconomic and ecological crisis: An example from the Amudarya River basin, Central Asia. Ecol. Soc. 2011, 16, 1-19. [CrossRef]

13. Alikuzai, H. A Concise History of Afghanistan-Central Asia and India in 25 Volumes; Trafford Press: Bloomington, IN, USA, 2015; Volume 10, pp. 425-428.

14. Kostianoy, A.B.; Kosarey, A.N. (Eds.) The Aral Sea Environment; Springer: Berlin, Germany, 2010.

15. Micklin, P. The future Aral Sea: Hope and despair. Environ. Earth Sci. 2016, 75, 844. [CrossRef]

16. Deng, H.; Chen, Y. Influences of recent climate change and human activities on water storage variations in Central Asia. J. Hydrol. 2017, 544, 46-57. [CrossRef]

17. Sorg, A.; Bolch, T.; Stoffel, M.; Solomina, O.; Beniston, M. Climate change impacts on glaciers and runoff in Tien Shan (Central Asia). Nat. Clim. Chang. 2012, 2, 725-731. [CrossRef]

18. World Bank Group. Turn Down the Heat; International Bank for Reconstruction and Development: Washington, DC, USA, 2014; pp. 182-188.

19. Abdullaev, I.; Rakhmatullaev, S. Setting up the agenda for water reforms in Central Asia: Does the nexus approach help? Environ. Earth Sci. 2016, 75, 870. [CrossRef]

20. Granit, J.; Jägerskog, A.; Lindström, A.; Björklund, G.; Bullock, A.; Löfgren, R.; de Gooijer, G.; Pettigrew, S. Regional options for addressing the water, energy and food nexus in Central Asia and the Aral Sea basin. Int. J. Water Res. Dev. 2012, 28, 419-432. [CrossRef]

21. Villiamayo-Tomas, S.; Grundmann, P.; Epstein, G.; Evans, T.; Kimmich, C. The water-energy-food security nexus through the lenses of the value chain and the institutional analysis and development frameworks. Water Altern. 2015, 8, 735-755.

22. Qi, J.; Bobushev, T.S.; Kulmatov, R.; Groisman, P.; Gutman, G. Addressing global challenges for Central Asian socio-ecosystems. Front. Earth Sci. 2012, 6, 115-121. [CrossRef]

23. National Aquaculture Sector Overview: National Aquaculture Sector Fact Sheets; FAO Fisheries and Aquaculture Department: Rome, Italy; Available online: http:/ / www.fao.org/fishery/countrysector/naso_russiafed/en (accessed on 3 August 2017).

24. Fishery and Aquaculture Profiles; FAO Fisheries and Aquaculture Department: Rome, Italy; Available online: http:/ / www.fao.org/ fishery/facp/UZB/en (accessed on 3 August 2017).

25. Timirkhanov, S.; Chaikin, B.; Makhambetova, Z.; Thorpe, A.; van Anrooy, R. Fisheries and Aquaculture in the Republic of Kazakhstan: A Review; Food and Agricultural Organization of the United Nations: Rome, Italy, 2010.

26. Akhmetov, A. (Chilik Pond Farm, Chilik, Kazakhstan). Personal communication, 2016.

27. Siebert, S.; Burke, J.; Faures, J.M.; Frenken, K.; Hoogeveen, J.; Döll, P.; Portmann, F.T. Groundwater use for irrigation-A global inventory. Hydrol. Earth Syst. Sci. Discuss. 2010, 7, 3977-4021. [CrossRef]

28. Peyrouse, S. The hydroelectric sector in Central Asia and the growing role of China. China Eurasia Forum Quart. 2007, 5, 131-148. 
29. Kraak, E.P. The geopolitics of hydropower in Central Asia: The Syr Darya. Asia Pac. J. 2012, 10, 1-10. Available online: http://apjjf.org/2012/10/15/Eelke-P.-Kraak/3737/article.html (accessed on 5 September 2017).

30. Rakhmatullaev, S.; Huneau, F.; Le Coustumer, P.; Motelica-Heino, M.; Bakiev, M. Facts and perspectives of water reservoirs in Central Asia: A special focus on Uzbekistan. Water 2010, 2, 307-320. [CrossRef]

31. Aslund, A. How Capitalism Was Built: The Transformation of Central and Eastern Europe; Russia and Central Asia; Cambridge University Press: Cambridge, UK, 2007.

32. Lavigne, M. The Economics of Transition: From Socialist Economy to Market Economy, 2nd ed.; St. Martin's Press: New York, NY, USA, 1999.

33. Overland, I.; Kjaernet, H.; Kendall-Taylor, A. (Eds.) Caspian Energy Politics: Azerbaijan, Kazakhstan and Turkmenistan; Routledge: London, UK, 2010.

34. Micklin, P. The Water Management Crisis in Soviet Central Asia. Carl Beck Papers in Russian and East European Studies No. 905; University of Pittsburgh: Pittsburgh, PA, USA, 1991.

35. Allan, A.; Steyl, I. Encouraging stakeholder participation in river basin management: A case study from the Nura River of Kazakhstan. Univ. Denver Water Law Rev. 2008, 12, 209-239.

36. Olcott, M. Central Asia's Second Chance; Carnegie Endowment for International Peace: Washington, DC, USA, 2005.

37. Olcott, M. Kazakhstan: Unfulfilled Promise? Carnegie Endowment for International Peace: Washington, DC, USA, 2010.

38. Olcott, M. Tajikistan's Difficult Development Path; Carnegie Endowment for International Peace: Washington, DC, USA, 2012.

39. Petr, T.; Mitrofanov, V.P. The impact on fish stocks of river regulation in Central Asia and Kazakhstan. Lakes Reserv. Res. Manag. 1998, 3, 143-164. [CrossRef]

40. Petr, T.; Mitrofanov, V.P. Fisheries in arid countries of Central Asia and in Kazakhstan under the impact of agriculture. In Papers Contributed to the Regional Symposium on Sustainable Development of Inland Fisheries under Environmental Constraints and IPFC Working Party of Experts on Inland Fisheries; Petr, T., Morris, M., Eds.; Food and Agricultural Organization of the United Nations: Rome, Italy, 1995; pp. 40-79.

41. Groll, M.; Kulmatov, R.; Mullabaev, N.; Opp, C.; Kulmatova, D. Rise and decline of the fishery industry in the Aydarkul-Arnasay Lake System (Uzbekistan): Effects of reservoir management, irrigation farming and climate change on an unstable ecosystem. Environ. Earth Sci. 2016, 75, 921. [CrossRef]

42. Micklin, P.; Aladin, N.V.; Plotnikov, I. (Eds.) The Aral Sea: The Devastation and Partial Rehabilitation of a Great Lake; Springer: Berlin, Germany, 2014.

43. Petr, T. Lake Balkhash, Kazakhstan. Int. J. Salt Lake Res. 1992, 1, 21-46. [CrossRef]

44. Ferguson, R. The Devil and the Disappearing Sea: A True Story about the Aral Sea Catastrophe; Raincoast Books: Vancouver, BC, Canada, 2003.

45. Breckle, S.-W.; Wucherer, W.; Dimeyeva, L.; Ogar, N. (Eds.) Aralkum-A Man-Made Desert: The Desiccated Floor of the Aral Sea; Springer: Heidelberg, Germany, 2012.

46. The Curse of Cotton: Central Asia's Destructive Monoculture; International Crisis Group: Brussels, Belgium, 2005; Available online: https:/ / d2071andvip0wj.cloudfront.net/93-the-curse-of-cotton-central-asia-s-destructivemonoculture.pdf (accessed on 4 August 2017).

47. Rahaman, M.M. Principles of transboundary water resources management and water-related agreements in Central Asia: An analysis. Int. J. Water Res. Dev. 2012, 28, 475-491. [CrossRef]

48. Water Energy Nexus in Central Asia: Improving Regional Cooperation in the Syr Darya Basin; World Bank: Washington, DC, USA, 2004; Available online: http://siteresources.worldbank.org/INTUZBEKISTAN/ Resources/Water_Energy_Nexus_final.pdf (accessed on 4 August 2017).

49. Central Asia: Water and Conflict; International Crisis Group: Brussels, Belgium, 2002; Available online: https:/ / www.crisisgroup.org/europe-central-asia/central-asia/uzbekistan/central-asia-water-andconflict (accessed on 4 August 2017).

50. Stone, R. Transboundary rivers for China and Kazakhstan; no meeting of the minds on water. Science 2012, 337, 405-407. [CrossRef] [PubMed]

51. Bekchanov, M.; Ringler, C.; Bhaduri, A.; Jeuland, M. How would Rogun Dam affect water and energy scarcity in Central Asia? Water Int. 2015, 40, 856-876. [CrossRef] 
52. The Rogun Dam: A Source of Division in Central Asia. Available online: http:/ / carnegie.ru/commentary / 66334 (accessed on 4 August 2017).

53. Renewable Freshwater Resources Per Capita. Available online: http://data.worldbank.org/indicator/ER. H2O.INTR.PC (accessed on 4 August 2017).

54. Dostaj, Z.D.; Giese, E.; Hagg, W. Wasserressourcen und deren Nutzung im Ili-Balchas Becken; Zentrum für internationale Entwicklungs-und Umweltforschung der Justus-Liebig-Universität: Giessen, Germany, 2006.

55. Thevs, N.; Beckmann, V.; Akimalieva, A.; Köbbing, J.F.; Nurtazin, S.; Hirschelmann, S.; Piechottka, T.; Salmurzauli, R.; Baibagysov, A. Assessment of ecosystem services of the wetlands in the Ili River delta, Kazakhstan. Environ. Earth Sci. 2017. [CrossRef]

56. Thevs, N.; Nurtazin, S.; Beckmann, V.; Salmyrzauli, R.; Khalil, A. Water consumption of agriculture and natural ecosystems along the Ili River in China and Kazakhstan. Water 2017, 9, 207. [CrossRef]

57. Imentai, A.; Thevs, N.; Schmidt, S.; Nurtazin, S.; Salmurzauli, R. Vegetation, fauna, and biodiversity of the Ile delta and southern Lake Balkhash-A review. J. Great Lakes Res. 2015, 41, 688-696. [CrossRef]

58. Chida, T. Science, development and modernization in the Brezhnev time. The water development in the Lake Balkhash basin. Cahiers du Monde Russe 2013, 54, 239-264.

59. Spivak, L.F.; Muratova, N.R.; Vitkovskaya, I.S.; Batyrbaeva, M.Z.; Alibaev, K.U.; Moldazhanov, S.G. The results of space monitoring system of reservoirs on Ile tributaries in China. In Water Resources of Central Asia and Their Use; Institute of Geography: Almaty, Kazakhstan, 2016; pp. 424-432.

60. Kudekov, T.K. (Ed.) Contemporary Ecological Status of Balkhash Lake Basin; Kagnat: Almaty, Kazakhstan, 2002.

61. Mitrofanov, V.P.; Dukravets, G.M.; Sidarova, A.F. Fishes of Kazakhstan: Introductions and Fisheries; Gylym: Almaty, Kazakhstan, 1992; Volume 5.

62. Lioubimtseva, E.; Cole, R. Uncertainties of climate change in arid environments of Central Asia. Rev. Fish. Sci. 2006, 14, 29-49. [CrossRef]

63. Wegerich, K. Water resources in Central Asia: Regional stability or patchy make-up? Cent. Asian Surv. 2011, 2, 275-290. [CrossRef]

64. On this Day, 26 October; Russiapedia: Moscow, Russia; Available online: http:/ /russiapedia.rt.com/on-thisday/october-26/ (accessed on 8 August 2017).

65. Abdullaev, I.; Rakhmatullaev, S. Data management for integrated water resources management in Central Asia. J. Hydroinform. 2014, 16, 1425-1440. [CrossRef]

66. Batie, S. Wicked problems and applied economics. Am. J. Agric. Econ. 2008, 90, 1176-1191.

67. Bazilian, M.; Rogner, H.; Howells, M.; Hermann, S.; Arent, D.; Gielen, D.; Steduto, P.; Mueller, A.; Komor, P.; Tol, R.S.J.; et al. Considering the energy, water and food nexus: Towards an integrated modelling approach. Energy Policy 2011, 39, 7896-7906. [CrossRef]

68. Propastin, P. Assessment of climate and human induced disaster risk over shared water resources in the Balkhash Lake drainage basin. In Climate Change and the Sustainable Use of Water Resources; Leal Filho, W., Ed.; Springer: Berlin, Germany, 2013; pp. 41-54.

69. Weitz, N. Cross-Sectoral Integration in the Sustainable Development Goals: A Nexus Approach; Stockholm Environment Institute: Stockholm, Sweden, 2014.

70. Bizikova, L.; Roy, D.; Swanson, D.; Venema, H.D.; McCandless, M. The Water-Energy-Food Security Nexus: Towards a Practical Planning and Decision-Support Framework for Landscape Investment and Risk Management; International Institute for Sustainable Development: Winnipeg, MB, Canada, 2013.

71. China's Dam Boom Stokes Concerns in Asia. Available online: https://asia.nikkei.com/Viewpoints/BrahmaChellaney / Brahma-Chellaney-China-s-dam-boom-stokes-concerns-in-Asia (accessed on 6 September 2017).

72. Revival of the Aral Sea: Kazakh and World Efforts to Restore the Island Sea. Available online: http://www.edgekz.com/revival-aral-sea-kazakh-world-efforts-restore-island-sea/ (accessed on 6 September 2017).

73. Water Wars in Central Asia. Available online: https://www.foreignaffairs.com/gallerys/2016-08-24/waterwars-central-asia (accessed on 6 September 2017).

74. Kazakhstan Unveils New Plan. Available online: http://www.world-grain.com/articles/news_home/ World_Grain_News/2017/01/Kazakhstan_unveils_new_plan.aspx?ID=\%7BBBCFF137-CB5E-4D6F-91365A155EDFA0CA\%7D\&p=1\&cck=1 (accessed on 6 September 2017).

75. EBRD Finances Irrigation in Three Regions of Kazakhstan. Available online: http://www.ebrd.com/news / 2017/ebrd-finances-irrigation-in-three-regions-of-kazakhstan-.html (accessed on 6 September 2017). 
76. World Bank to Help Kazakhstan Modernize Irrigation System. Available online: http:/ / www.worldbank. org/en/news / press-release/2014/04/29/world-bank-to-help-kazakhstan-modernize-irrigation-system (accessed on 6 September 2017).

77. Turkmen Leader Calls for End to Free Water, Gas and Power. Available online: https://www. thenews.com.pk/print/209254-Turkmen-leader-calls-for-end-to-free-water-gas-and-power (accessed on 6 September 2017).

78. Uzbekistan: King Cotton Confronts Caper Uprising. Available online: http://www.eurasianet.org/node/ 84526 (accessed on 6 September 2017).

79. Will Central Asia Water Wars Derail China's Silk Road? Available online: http:/ / thediplomat.com/2017/ 03/will-central-asia-water-wars-derail-chinas-silk-road/ (accessed on 6 September 2017).

80. Interview: Central Asia Copes with Climate Change. Available online: http://thediplomat.com/2017/08/ interview-central-asia-copes-with-climate-change/ (accessed on 6 September 2017).

81. Uzbekistan Opens Door to Central Asian Integration. Available online: https://asia.nikkei.com/print/ article/283403 (accessed on 6 September 2017).

82. New Fish Hatchery and Aqua-Feed Unit Inaugurated in Kyrgyzstan. Available online: http:/ / kg.one.un.org/content/unct/kyrgyzstan/en/home/news/kg-news/2016/new-fish-hatcheryand-aqua-feed-unit-inaugurated-in-kyrgyzstan/ (accessed on 6 September 2017).

83. Russia to Further Cut Fish Imports with New Crimean Processing Plant. Available online: https:// thefishsite.com/articles/russia-to-further-cut-fish-imports-with-new-crimean-processing-plant (accessed on 6 September 2017).

84. The River of Hope. Available online: http://livingasia.online/water/eng_taj_water (accessed on 6 September 2017).

85. Schechter, M.G.; Blue, D.J. The inadequacy of contemporary international governance of fisheries ecosystems. In Sustainable Fisheries: Multi-Level Approaches to a Global Problem; Taylor, W.W., Lynch, A.J., Schechter, M.G., Eds.; American Fisheries Society: Bethesda, MD, USA, 2011; pp. 252-299.

86. Hale, H. Patronal Politics: Eurasian Regime Dynamics in Comparative Perspective; Cambridge University Press: Cambridge, UK, 2015.

87. Graham, N. The prospect for regional governance of inland fisheries in Central Eurasia. In Freshwater, Fish and the Future: Proceedings of the Global Cross-Sectoral Conference; Taylor, W.W., Bartley, D.M., Goddard, C.I., Leonard, N.J., Welcomme, R., Eds.; American Fisheries Society: Bethesda, MD, USA, 2016; pp. 333-341. 